crop, they most certainly do develop strains which are easy to harvest. Strains are not developed to suit the capabilities of "the" machine but of a genre of machines.

I see no point in growing the greatest possible amount of fibre per acre if it is extremely difficult to harvest. We don't have to wait $50-60$ years to be able to harvest "any size of tree" economically; we can do it now providing all the trees are of essentially the same size. This is the critical feature, and I know of not a single logging engineer who foresees a machine that is equally efficient while processing one-inch and 10-inch trees (please forgive the Eastern pulpwood standards). The processors available now and in the foreseeable future are all linear and their productivity is therefore closely related to the tree size. They operate best where tree size has a limited range and the machine is adapted to that range. This is not growing a crop to fit "the" machine but to fit a genre of machines.

It is absolutely certain that our future crops must have uniformly large trees with relatively high volume per acre if the logging engineer is to be able to solve the harvesting problems economically.

I agree that with balsam fir we can produce more pulp by crowding more trees on each acre. But I am not at all certain the same is true in any other species. It is far too early to rush in with generalizations especially since fir is so tolerant. In any event, large amounts of fibre per se are useless if the "packages" are of such widely assorted sizes as to make harvesting costs over-ride the value of the increased organic production.

Our separation of silviculturists and loggers in North America has resulted in a "let George do it" attitude in Soth groups and I am not as confident as Vincent that the engineer will solve the harvesting problem if we just grow a large volume crop of unspecified dimensions.

RASKERVILLE P. O. Box 4,000, Fredericton, N.B.

\title{
A Field Forestry View on Research
}

In the December Forestry Chronicle, Dr. Nordin compared two prominent foresters, who expressed publicly their opinion on forest research, to the ignorant citizens of Lancaster, who more than a century ago condemned the invention of the steam locomotive. I was not present at that meeting. However I know that those two foresters represent the group of men, who want to start forestry practice with our present knowledge. We do not want to wait until our research foresters will tell us the results of their numerous long term projects.

We dirty field foresters can see the increased accumulation of unrestocked cutover areas. We have enough vision to visualize the forestry situation in Canada 50 to 60 years from now. We are not against forestry research, but having the sense of moral and professional responsibility for the future of our forests, we believe that keeping our forest land in continuous productivity must have an unconditional priority.

Two hundred years ago European foresters faced the same dilemma. They had a lot of mismanaged forests but no forestry books and no forestry schools. But they had common sense, sense for responsibility, enough vision, and last 
but not least, affection for the forests. They started to manage forests on a sustained yield basis. They made many mistakes, but mostly they created practicing silviculture more as an art than as a science-valuable and beautiful forests. Schools, textbooks, research had to wait. As the result of intensive forest management the establishment of good forestry schools and the demand for forestry research followed. The first lecturers came to the classrooms in field uniforms. We have good forestry schools, we have more and better equipped research institutes than any western European country and we are happy to have them, but we can not afford to wait any longer.

We, ordinary field foresters, need your support, Dr. Nordin. We can talk forestry. only to ourselves. You, like other prominent scientists and research foresters, have the opportunity to meet our legislators and leaders of our economy. We beg you, do not tell them anything but the truth. Can you do it?

L. VIDLAK,

49 Strathcona Ave., Port Arthur, Ont. 